\title{
NATURE IS LOCAL WISDOM TREASURES IN INDONESIA ECOTOURISM
}

\author{
Miya Dewi Suprihandari, Muhammad Ali Masyhuri, Teguh Purnomo, Menur \\ Kusumaningtyas, Nurul Iman, Muhammad Aly Umar \\ miyadewi@stiemahardhika.ac.id, mohammad.ali@stiemaharhdika.ac.id, \\ purnomo_teguh@untag-banyuwangi.ac.id, \\ menur.kusumaningtyas@stiemahardhika.ac.id,nuruliman@ubhara.ac.id, \\ tagirwijaya99@stiefatahilah.ac.id
}

\begin{abstract}
Kampung and tourism villages in Indonesia are a positive phenomenon that can function as an effort to increase the income of the village or village community directly and indirectly for local and central government. Efforts to present the local wealth of the region as an added value of an area, so that the growth rate of tourist visits in an area in Indonesia is increasing from the past. The number of village and tourist village destinations in Indonesia has also increased from the past and entrepreneurial activities have become an option for most members of village and tourism village communities in various forms. Efforts to explore and develop local capabilities and wealth will provide optimal results when the government provides full support for the capabilities and creativity of local communities in all matters, including training for community members who are interested and have a desire to increase knowledge and increase their creative abilities, so that they can become human resources who are able to compete in the future and have character. This support is carried out continuously because villages and tourist villages in Indonesia currently also have an educational function for all ages and levels of education.
\end{abstract}

Keywords: village and tourism village, human resources, local wealth-based entrepreneurship

\section{INTRODUCTION}

Various efforts can be made jointly by the government and society in an effort to increase the economic capacity of a region. This work can also be done in many different areas. Currently, efforts to introduce local wealth to people outside the region and the state are currently being carried out by the people of an area independently or together with the local government. The tourism sector is one of the areas that is quite interesting to develop, so that the economic conditions of the people in tourist areas can be better (Boripunt, Wannaporn, et. al, 2010).

Indonesia as an archipelagic and agricultural country has a variety of local wealth that can be extracted and processed in order to increase the economic capacity of the community. The local wealth of the Indonesian nation is spread across the oceans to the 
mountains, from Sabang to Merauke. This variety of wealth is a treasure that will never end if it is explored and processed wisely by the government and all the nation's children. With all the capabilities of all Indonesian children, the management of existing local natural resources will be a source of income for local communities and the state.

The tourism sector is a promising field in an effort to increase the income of a region and a country. The variety of natural conditions presented in Indonesia is a gift that many other nations in the world do not have. This condition has become an inspiration for people in tourist areas and the Indonesian government, both local and central, to produce various extraordinary things. This ultimately becomes a tremendous attraction for domestic and international tourists (Boripunt, Wannaporn, et. al, 2010)..

Human resources are important in addition to natural factors, capital, technology and capital (funds) in an effort to develop the tourism sector. The tourism area community is the main source of informants for the development of a tourist area, apart from the local government. Everything related to the local resources of the tourist area must be considered very much so that it will not change or even be damaged when the tourism sector in the area starts and experiences very rapid development. Because every local wealth that exists is a legacy from our ancestors that must be protected from all kinds of disturbing and destructive things (Calderon, Kim D., A.Nguyen, Hai D, 2017).

\section{LITERATURE REVIEW}

\section{Village and Tourism Village}

Indonesia is an agricultural and archipelagic country that has various local natural resources, from the West to the East. Almost all regions in Indonesia consist of many villages that form a village, a cluster of villages eventually forms a sub-district / district, and a collection of sub-districts / districts is able to form a city. Each village and village throughout Indonesia each has different characteristics, so that each village and village has different potential local natural resources. These characteristics have become the starting point for efforts to develop the tourism sector in every village and village in Indonesia (Calderon, Kim D., A.Nguyen, Hai D, 2017).

Tourist villages are not only in rural areas, but are now found in several urban areas in Indonesia. Tourist villages in urban areas usually present things related to the creative ability of the community to process what they get around them. In general, they cultivate or make the conditions around them into new fields of business for the village community itself and the people around the village. This has resulted in a better economic condition for the surrounding community and related local governments (Campbell, Lisa M., 1999).

Tourism villages are creative efforts of rural communities in several regions in Indonesia. This type of village not only presents a beautiful and comfortable rural atmosphere, but also presents various processed products from rural areas. A tourism 
village in general is not only a natural tourism location, such as a tourist village, a tourist village is also a reference location for education for school students and the general public with different ages and education levels. At present, several tourist village locations have also accommodated the various needs of domestic and nondomestic tourists without leaving and disturbing their traditional values (Campbell, Lisa M., 1999).

\section{Human Resources}

Residents of village communities and tourist villages in Indonesia today are not ordinary citizens. The increasingly advanced global conditions have also influenced their mindset, especially in the field of technology. So that they have turned into a society that is very creative and willing to learn about new things without having to leave or forget the noble values of the nation (Đukić, V, Volić, I, 2017). Although, technological advances have not been fully accepted and well understood by some members of rural communities.

For some members of the village and tourist village communities, technological progress is something they really need in an effort to support their needs to develop. Advances in technology make the process of learning about many new things easier, although government assistance is still needed to guide people to become more creative human resources (Đukić, V, Volić, I, 2017). The government should always provide guidance to village communities and tourist villages so that they become a community resource that has the ability to compete at the local and international levels. When they have developed into human resources who have the ability to compete and have character, the activities of developing villages and tourist sites will turn out to be of great value.

Education and training for members of the village community and tourist villages should remain the main things that should not be forgotten. Efforts to maintain and improve educational materials in these areas are the government's efforts to maintain and improve the quality of community resources in villages and tourist villages. Everything related to global progress should also be made available, so that the learning process of the young generation and the productive generation in villages and tourist villages is able to develop and grow into human resources who have character and have the ability to compete wherever they are and in any condition (Gorbachev, Mikhail, 2000). So that the noble values of the nation are maintained in the character of the human resources of the villages and tourist villages in Indonesia, even though global conditions have changed so rapidly.

\section{Local Wisdom Based Entrepreneurship}

Local natural wealth owned by villages and tourist villages is not cheap. These local sources of natural wealth have high competitive and economic value, so they can help the villagers and tourism villages increase their income. Kampong and tourism 
villages in Indonesia take many forms, ranging from villages and tourist villages in the mountains, there are even villages and tourist villages on the coast that offer a variety of local natural wealth. The local wealth of each tourist village and village ultimately becomes a competitive attraction for tourists.

When a village and a village change its condition to become a tourist location, it is certain that entrepreneurial activities are an option for many members of the community, including in the service sector. This is caused by the emergence of requests or needs of tourists who visit or even live temporarily around the area or at the tourist location. Entrepreneurial activities in villages and tourist villages as well as in the surrounding areas will generally explore and process natural resources around the location so that they become new products that are attractive to tourists and have high economic value. In the end, local wealth-based entrepreneurial activities are also able to provide solutions for the government in order to reduce unemployment and urbanization (Gorbachev, Mikhail, 2000).

In general, local wealth-based entrepreneurs are members of society who have a high level of creativity. They are people who are able to think creatively to increase the economic value of a local wealth by taking one or more actions. These local wealthy entrepreneurs will also take advantage of the cooperation with the government to increase income and expand the market for their products. The collaboration carried out generally takes the form of training related to hard skills and soft skills, which have generally been carried out by the government since the scope of senior secondary education, so that hard skills and soft skills have been trained from the start for the interested productive generation (Krüger, Oliver, 2005).

\section{RESEARCH METHOD}

This research is a type of research that uses qualitative methods where this research seeks to convey the latest conditions related to phenomena that are the focus of research (Supriadi, 2020). This phenomenon is a phenomenon of the growth and development of villages and tourist villages in Indonesia based on descriptive local wealth.

\section{FINDINGS}

Indonesia is an agricultural country as well as an archipelago that has a variety of cultures and local natural resources. The Indonesian nation has many villages and villages in both mountainous and coastal rural areas with a variety of local assets that characterize each region and their competitive selling points (Krüger, Oliver, 2005). The results of extracting and managing various local assets will eventually become a new source of income for the community and local and central government. Continued management and processing will ultimately provide assistance to the government in its efforts to address labor problems. 
Each region in Indonesia has its own characteristics and strengths related to its local wealth. The local wealth possessed by each region has various forms, both in the form of culture, processed products and others. Its culture and local products are able to attract local and international tourists. This eventually opens up or creates new jobs that are able to absorb local workers and even workers who come from outside the area (Wood, E. Et. al, 2015).

In recent years, the phenomenon of villages and tourist villages in Indonesia has emerged. In general, these areas display the cultural side and natural conditions around them as well as the original processed products of the area. Many cultural sides are displayed because they are different and although they are not only owned by the area, usually some of these cultures have similarities with cultures from other regions with different names. Although in fact each region still has its own characteristics that are identical to each of these regions .

The number of villages and tourist villages in Indonesia has increased every year based on information from government reports. Based on data compiled by the government, in this case the Ministry of Tourism and Creative Economy, the number of villages and tourist villages has increased from 2018 to 1,734. In other words, the number of tourist villages has increased to 10,000 around 2020. This fact conveys that the development of the tourism sector is increasing in almost all regions in Indonesia (www.kemenparekraf.go.id).

In the areas around East Java, currently there are many new tourist areas, both in mountainous, rural, and even coastal areas. Currently, several areas on the mountainous slopes of East Java have turned into tourist villages by "selling" their natural conditions and conditions. In addition, they also market the natural products in their environment, which are generally agricultural and livestock products. Not all agricultural and livestock products are sold in the form of raw products, but also some of them have been processed into a variety of new products that have higher economic value (Maryani, E, Yani, A, 2016).

When people in mountainous areas produce their own processed agricultural and livestock products, this will indirectly provide more positive results in terms of the economy of the people. In general, the people in the tourist area and the surrounding area will begin to prepare everything that can support the marketing process of the tourist area (Maryani, E, Yani, A, 2016). Usually they will also set up lodging and processed product shopping center areas in nearby locations, so that tourists who plan to spend their vacation can freely stay while enjoying the culinary provided around their area of stay. This will usually be a plus for these tourist areas and can be an attraction for potential tourists or visitors, as well as a free promotional tool for these tourist areas.

Meanwhile, in other coastal areas of Indonesia, many people in the area around the coast and in areas several kilometers from the center of the coast have even started to 
clean up and prepare everything they think is capable of supporting their regional marketing activities. The people are still trying their best to process local products that have been their mainstay so far in order to satisfy the culinary desires of visiting tourists. In fact, still around East Java, this coastal area has improved many locations that are considered potential to attract local and foreign tourists to visit and spend their vacation time there. The local community has also prepared the cultural activities of the surrounding community to become one of the interesting activities that can become an attraction for visiting tourists (Muehlenbein, Michael P., 2018).

The daily activities that have become the culture of the people in several tourist areas or the daily activities of the community, such as making batik or farming in the fields have become some of the activities that are of interest to visiting tourists. Things that are interesting like that are new things for tourists who generally come from urban areas. So that moments like that become moments that most visiting tourists want to live with. In fact, some of these places have also become one of the places recommended by visitors or tourists to other tourists (Stronza, A, Gordillo, J., 2008).

Currently, tourists make villages and tourist villages as alternative tourist attractions besides the existing tourist attractions. This makes regional and central governments pay more attention to areas that are far from urban areas and are considered to have potential as alternative tourist areas (Muehlenbein, Michael P., 2018). Today's people have seen a lot of better conditions and situations in areas that previously had natural potential but had not been touched by government interference in the past. So that currently these areas are able to turn into alternative tourist locations that contribute a lot to increasing the income of the local community itself and the regional government, as well as the central government (Wood, E. Et. al, 2015).

Even the current tourism destination community activities and local governments and the central government have done a lot of things that are considered capable of being a medium for promoting tourism potential in the area. In some areas, traditional activities of the region are even becoming a permanent agenda in order to attract domestic and foreign tourists to come and get to know the area more. Agricultural produce in another area has even become a tourist attraction that is quite attractive to tourists, including coffee and fresh tea produced in the producing area. For this reason, the local and central government collaborates with local communities to try to promote through various efforts, most of which are done by them, including creating social media accounts for their area and uploading many interesting portraits of many things people do and whatever their agricultural products have, as well as the natural conditions in which they live are very beautiful (Myftari, S, et. al, 2012).

The side effect of the increasing number of villages and tourist villages at this time is the emergence of a variety of new jobs for the surrounding community and people in the area of origin of tourists. Various creative efforts of the community in villages and tourist villages arise when various creative thoughts regarding the process of producing 
various alternative processed products derived from agricultural and livestock products as well as the creative results of processed products derived from natural materials available around them, for example woven fabrics, and others. The construction of many shelters or inns has created many promising employment opportunities for people of productive age in these villages and tourist villages, including officers who guard open houses and officers who serve tourists in open houses or inns they rent. The culinary business that serves authentic local home cooking menus has also become a source of new employment for many families around or in the village and tourist village environment (Reimer, J. K.Kila, Walter, Pierre, 2013).

Many new sources of employment are also found in the areas of origin of tourists who wish to visit many villages and tourist villages at this time. What is most commonly encountered today is the development of tourism transportation businesses that serve community groups who want to take a vacation. In general, the tourism transportation business will collaborate with many decent resting places and restaurants and have agreed to cooperate. These various new job opportunities ultimately help the government in its efforts to reduce the number of productive workers and creative housewives who still do not have income, and the rate of urbanization from regions to big cities can be reduced or even prevented (Wood, E., et. al, 2008).

The decision to work as an entrepreneur in many rural areas and tourist villages has become a positive phenomenon for most of the community. This is supported by the condition of the tourist area which does have great potential which is very likely to be developed by members of the community who are characterized and creative. They will process their natural resources, including the culinary sector, into a product that is able to attract consumers from other areas who visit their villages and villages. This community group is obliged to be supported by the central and regional governments so that they are able to help the government reduce the number of their own local unemployed as well as unemployment that comes from them and does not get a job in their destination city (Stronza, A, Gordillo, J., 2008).

In the end, these entrepreneurial activities are also able to reduce the number of people who are left behind in several ways. Because finally the government also helps them by holding training in the context of empowering creative communities in order to increase their abilities and creativity so that they can compete with human resources anywhere (Weaver, David B. Lawton, Laura J.., 2007). Currently, there are many local entrepreneurs who have become exporters in Indonesia. The processed products they produce are well known and owned by many visiting tourists who come from other parts of the world.

When the amount of family income in the villages and tourist villages gets better, it can be seen that the health conditions of the people there are also getting better. The number of children dropping out of school can also be reduced as the family income increases. Likewise, the level of housing feasibility has also increased, because in the 
end they were able to improve the living conditions of some of them who previously were still not feasible. So that the economic conditions of a more prosperous community can ultimately be seen in many villages and tourist villages spread across Indonesia, both in rural areas under the mountains, as well as around the coast (Wood, E., et. al, 2008).

\section{CONCLUSION AND SUGGESTION}

Alternative tourism has become a new trend in Indonesia with many new tourism villages and villages in Indonesia. Almost all of these villages and tourist villages "sell" the potential for natural beauty and other natural wealth, as well as the traditional culture of their people. In general, each village and tourism village also has the traditional culture of the community which tends to be different. This is certainly able to attract a lot of domestic and foreign tourists.

Along with the development of the tourism sector related to villages and tourism villages, it can be ascertained that an improvement in the economic conditions of the creative community in the area will also occur. The improvement in the economic conditions of the creative community is also related to the increased capacity of the creative economy group in the community. Currently, this creative community economic group can be said to always be making efforts to increase creativity by holding training activities in collaboration with related government agencies (Weaver, David B. Lawton, Laura J.., 2007). Even now, many private institutions that care about them also provide training to help efforts to increase the creativity of creative community economic groups in rural areas and tourist villages through the CSR program.

The training efforts that have been received by the people of the village areas and tourist villages in general cover many things. The training not only seeks to help cultivate the wealth of local wisdom in their area, but also seeks the efforts of the community to always protect, care for and manage the environment and natural resources they have. In general, these training activities are not only for people of productive age but also include housewives, school children and all community members in these villages and tourist villages. So that the process of maintaining, caring for and managing natural resources and other potential natural wealth is the responsibility of the members of the village and tourism village communities (Scheyvens, Regina, 1999).

In addition to processing and creating processed products originating from local wealth sources in the village area and tourist villages, village and tourism village human resources are also expected to be able to become people who always follow the times without leaving and forgetting the cultural values of their ancestors. When times and technology are increasingly developing, the people of rural areas and tourism villages are also able to produce something new and interesting from their area, then introduce it 
to people from outside their area using existing technological advances. The internet is also the tool most needed by the village community and tourist villages that exist today. Technology becomes a means for villagers and tourism villages to introduce or promote their area and all the potential they have to the outside world through the social media they have prepared (Reimer, J. K.Kila, Walter, Pierre, 2013).

When the villagers and tourism villages have acquired new knowledge through the process of training and community empowerment, tourism institutions through the local government and village communities and tourist villages have high hopes that these villages and tourist villages will be more attractive to domestic and non-local visitors. domestic. When the number of visitors to villages and tourist villages increases, the regional and state revenues will automatically increase. To maintain the stability of economic conditions and the stability of environmental conditions towards the tourist areas and tourist areas itself, it is hoped that the central government through regional governments will also pay more attention, assist or strive for the creation of better facilities and infrastructure (Wood, E. Et. al, 2015).. Because if the facilities and infrastructure leading to the village and tourist village areas are better and better maintained, tourists will not experience difficulties and always want to return to the village tourist sites and tourist villages (Myftari, S, et. al, 2012).

In essence, training and empowerment of village communities and tourism villages is something that must be done by the local government through tourism institutions. After the training and community empowerment activities are carried out, they should not be forgotten, but they should still be given assistance in the process. In the end, this assistance activity will be able to become a positive impetus for all members of the community in an effort to develop and maintain stability and preservation of natural conditions and the economy of the community in the village areas and tourist sites (Scheyvens, Regina, 1999). When the stability and preservation of natural conditions and the economy of the people of the village and tourist areas are able to be maintained without having to change and forget about the noble cultural values they have in the global era, it is believed that these villages and tourism villages will be a source of economic improvement and as well as several other fields, including the population sector in the territory of the Indonesian state in general, and the village and tourism village areas in particular (Wood, E. Et. al, 2015). 


\section{REFERENCES}

Boripunt, Wannaporn, et. al, 2010, Ecotourism Management, The Global Studies Journal

Calderon, Kim D., A.Nguyen, Hai D, 2017, Sustainable Dynamics: A framework for creative collaborations for sustainable development in Bali, Indonesia, JPAIR Multidisciplinary Research Journal

Campbell, Lisa M., 1999, Ecotourism in rural developing communities, Annals of Tourism Research Journal

Đukić, V, Volić, I, 2017, The importance of documenting and including traditional wisdom in community-based ecotourism planning: A case study of the Nature Park Ponjavica in the village of Omoljica (Serbia), SAGE Open Journal

Gorbachev, Mikhail, 2000, Editorial: Employment and environment, Naturopa Journal

Krüger, Oliver, 2005, The role of ecotourism in conservation: Panacea or Pandora's box?, Biodiversity and Conservation Journal

Maryani, E, Yani, A, 2016, Local wisdom of kampung naga in mitigating disaster and its potencies for tourism education, Man in India Journal

Muehlenbein, Michael P., 2018, Ecotourism, Travel Medicine Book

Myftari, S, et. al, 2012, Eco-tourism development in the area of Prespa, Albania. International Journal of Ecosystems and Ecology Science (IJEES)

Reimer, J. K.Kila, Walter, Pierre, 2013, How do you know it when you see it? Community-based ecotourism in the Cardamom Mountains of southwestern Cambodia, Tourism Management Journal

Scheyvens, Regina, 1999, Ecotourism and the empowerment of local communities, Tourism Management Journal

Supriadi, I., 2020. Metode Riset Akuntansi. Deepublish.

Stronza, A, Gordillo, J., 2008, Community views of ecotourism, Annals of Tourism Research Journal

Weaver, David B. Lawton, Laura J.., 2007, Twenty years on: The state of contemporary ecotourism research, Tourism Management Journal 
Wood, E., et. al, 2008, Urban Forest and Rural Cities: Multi-sited Households, Consumption Patterns, and Forest Resources in Amazonia, Ecology and Society Journal

Wood, E. Et. al, 2015, Ecosystem Services Flows: Why Stakeholders' Power Relationships Matter, PLoS One Journal

www.kemenparekraf.go.id 